\title{
Chemical Analyses, Antimicrobial and Antioxidant Activities of Extracts from Cola nitida Seed
}

\author{
Julius K. Adesanwo ${ }^{1 *}$, Seun B. Ogundele ${ }^{1}$, David A. Akinpelu ${ }^{2}$ and Armando G. McDonald ${ }^{3}$ \\ ${ }^{1}$ Department of Chemistry, Obafemi Awolowo University, Ile-Ife, Nigeria; ${ }^{2}$ Department of Microbiology, Obafemi Awolowo University, \\ Ile-Ife, Nigeria; ${ }^{3}$ Department of Forestry, Rangeland and Fire Sciences, University of Idaho, Moscow, ID 83843, USA
}

\begin{abstract}
Background and Objectives: Medicinal plants are the richest, cheapest and most readily available source of drugs, nutraceuticals and food supplements. Pharmaceutical industries still rely largely on medicinal plants for intermediates due to their chemical diversities. This study, therefore, investigated the chemical constituents, thermal decomposition products and biological activities of extract from seeds of Cola nitida (the 'kola nut').

Methods: The pulverized seed was sequentially extracted with dichloromethane and methanol $\mathrm{CH}_{3} \mathrm{OH}$. The extracts were analysed directly by Fourier Transform Infra-Red, electrospray ionization mass spectrometer and as fatty acid methyl ester and trimethylsilyl derivatives by gas chromatography-mass spectrometry (GC-MS). The $\mathrm{CH}_{3} \mathrm{OH}$ extract was analysed by high-performance liquid chromatography for sugars. The intact and extracted seed biomasses were analysed directly by pyrolysis GC-MS. For isolation of chemicals and assessment of biological activity, a large scale $\mathrm{CH}_{3} \mathrm{OH}$ extraction was performed and the extract partitioned with n-hexane, ethyl acetate (EtOAc) and butanol. Fractionation was done using various chromatographic techniques. Antimicrobial and antioxidant activities of the extract, fractions and isolated caffeine were respectively determined by the methods of agar-well diffusion and 2,2-diphenyl-1-picrylhydrazyl radical scavenging.
\end{abstract}

Results: Caffeine and hexadecanoic acid were isolated from the EtOAc fraction while theobromine, caffeine, catechins, procyanidins, proanthocyanidins, sugars, fatty acids, alcohols and sterols were identified in the extracts. Multitude (62) biomass degradation products were identified in pyrolysed seed samples. The extract and fractions showed varying activities against most of the tested microbes, except against Shigella species, for which neither the extract nor fractions elicited any response. The butanol fraction exhibited the highest antioxidant activity.

Keywords: Cola nitida; Caffeine; $n$-Hexadecanoic acid; Catechin; Antimicrobial; Antioxidant; GC-MS; ESI-MS.

Abbreviations: AGC, Acelerated Gradient Chromatography; ${ }^{13} \mathrm{CNMR}$, Carbon 13 Nuclear magnetic resonance spectroscopy; CND, Cola nitida dichloromethane extract; CNM, Cola nitida methanol extract; $\mathrm{IC}_{50}$ value, concentration of samples leading to $50 \%$ reduction of initial DPPH radical concentration; $\mathrm{CDCl}_{3}$, deuterated chloroform; DCM or $\mathrm{CH}_{2} \mathrm{Cl}_{2}$, dichloromethane; DPPH, 2,2-diphenyl-1-picrylhydrazyl; ESI-MS, electrospray ionization mass spectrometer; EFAs, essential fatty acids; EtOAc, ethyl acetate; FAME, fatty acid methyl ester; FAs, fatty acids; FTIR, fourier transform infrared; GC-MS, gas chromatography-mass spectrometry; GRAM +ve, Gram positive; GRAM -ve, Gram negative; HPLC, high-performance liquid chromatography; IS, internal standard; $\mathrm{CH}_{3} \mathrm{OH}$, methanol; ${ }^{1} \mathrm{HNMR}$, proton nuclear magnetic resonance spectroscopy; Pyro GC-MS or Py GC-MS, pyrolysis gas chromatographymass spectrometry; Ag, silver; TLC, thin-layer chromatography; TMS, trimethylsilyl; UV, Ultra- violet; ZnSe, Zinc Selenium.

Received: April 28, 2017; Revised: June 23, 2017; Accepted: June 28, 2017

*Correspondence to: Julius K. Adesanwo, Department of Chemistry, Obafemi Awolowo University, Ile-Ife, Nigeria. Tel: +234-8030821561, E-mail: adesanwojk@ yahoo.com or julius08@oauife.edu.ng

How to cite this article: Adesanwo JK, Ogundele SB, Akinpelu DA, McDonald AG. Chemical Analyses, Antimicrobial and Antioxidant Activities of Extracts from Cola nitida Seed. J Explor Res Pharmacol 2017;2(3):67-77. doi: 10.14218/ JERP.2017.00015.
Conclusions: This report gives insight into the chemical constituents in Cola nitida seed, details the thermal decomposition constituents and establishes the antimicrobial and antioxidant activities of the seed extract and fractions, thereby contributing to the knowledge on the chemistry and pharmacology of the genus.

Introduction

Cola nitida (Vent) Schott et Endl, family Malyaceae, is a tree native to the rainforest of tropical West Africa. The seed or nut commonly called 'kola nut' is a popular stimulant in West Africa. It is called "Obi gbanja" by Yorubas in western Nigeria, "Goro" by Hausas in the north, and "Oji" by Ibos in the east. ${ }^{1}$ It is mainly used for nutritional purpose, eaten across cultures in West Africa, and 
has great social, religious and medicinal importance as well. ${ }^{2}$ Kola nut extracts are used in the manufacture of various non-alcoholic beverages, soft drinks, wines, chocolate and sweets. ${ }^{3-5}$

Previous researchers have reported a number of secondary metabolites from the kola nut, including caffeine, theobromin, catechin, epicatechin, procyanidins and proanthocyanidins. ${ }^{6-8}$ Aliphatic and heterocyclic amines in different species of cola have been reported as well, ${ }^{9}$ and quinic, tannic and chlorogenic acids have been found as present in the kola nut. ${ }^{10}$ Caffeine was the major alkaloid identified in Cola seeds and was considered as one of the signature compounds due to its concentration range. ${ }^{6}$

Knebel and Higler showed that fresh kola nut contained a glucoside named "kolanin", reporting that it is readily hydrolysed or split into glucose and caffeine in ripe or dried fruit. ${ }^{7}$ Kola nuts are rich in xanthine alkaloids, such as theobromine, caffeine, kolatin and kolanin. While caffeine stimulates the body, kolatin stimulates the heart. ${ }^{11,12}$ These constituents (caffeine, theobromine, and theophylline) in kola nut extract have been shown to contribute to the anti-photodamage effect, including wrinkles, and to elicit antioxidant and anti-aging activities, including suppression of UVinduced erythema, and to decrease skin roughness and scaling by topical or oral application. ${ }^{13}$

Nowadays, pathogenic microorganisms are developing resistance to existing antibiotics at an alarming rate. Extract of the leaves, root and stem bark of Cola nitida are extensively used in folk medicine. ${ }^{6}$ Different parts of Cola nitida have been exploited for different biotechnological applications. For instance, cola pods have been used for production of fructosyltransferase, an important enzyme for the synthesis of fructooligosaccharides, ${ }^{14}$ and most recently for the biosynthesis of silver ( $\mathrm{Ag}$ ) nanoparticles and silver-gold alloy nanoparticles for diverse biomedical applications, ${ }^{15-19}$ such as antimicrobial, antioxidant, anticoagulant and thrombolytic activities.

Similarly, the seed and seed shell extracts of Cola nitida have been used for green synthesis of Ag nanoparticles, showing profound antibacterial activities. ${ }^{20}$ In Uganda, extracts of the seed and leaves are used in treatment of sexual and erectile dysfunctions. ${ }^{21}$ In Nigeria, methanol extract of the seed is used against emesis and migraine. ${ }^{22}$ The aqueous extract of the seed has also been used as flavouring in carbonated drinks. ${ }^{23}$ Kola nut extract also demonstrates good protective property against red cell degradation. ${ }^{9}$

The aims of this study were to: (i) determine the composition of kola nut dichloromethane $\left(\mathrm{CH}_{2} \mathrm{Cl}_{2}\right)$ and $\mathrm{CH}_{3} \mathrm{OH}$ extracts by a combination of electrospray ionization-mass spectrometry (ESI-MS) and gas chromatography-mass spectrometry (GC-MS) analyses; (ii) determine the antimicrobial and antioxidant activity of the extracts; and (iii) isolate the active principle component(s).

\section{Experimental}

\section{General}

All thin-layer chromatography (TLC) analyses were performed at room temperature using pre-coated plates (silica gel $60 \mathrm{~F}_{254} 0.2$ $\mathrm{mm}$; Merck). Detection of spots was achieved by staining with iodine crystals and exposure to ultraviolet light (254 and 366 $\mathrm{nm})$. Melting point determination was carried out using a Gallenkamp apparatus. Accelerated gradient chromatography (Baeckstrom Separo AB) was carried out using silica gel (Kieselgel 60G $0.040-0.063 \mathrm{~mm}$ ) and column chromatography using silica gel, with a 60-200 mesh for fractionation. Proton Nuclear magnetic resonance $\left({ }^{1} \mathrm{HNMR}\right)$ spectroscopic data were recorded on a NMR machine (Agilent Technologies) at $400 \mathrm{MHz}$ and at $100 \mathrm{MHz}$ for ${ }^{13} \mathrm{CNMR}$. Chemical shifts of signals were reported in parts per million (ppm).

\section{Collection of plant material}

The plant material (kola nut) was collected at Alaro Farm Settlement, Ile-Ife, identified and authenticated at the Department of Pharmacognosy, Obafemi Awolowo University (Voucher Number FPI 2052).

\section{Sample preparation and extraction}

The seeds were dried at $60{ }^{\circ} \mathrm{C}$ for $48 \mathrm{~h}$, and milled to particle size of $1 \mathrm{~mm}$. Moisture content was determined in duplicate before extraction. The plant material was Soxhlet extracted (40 g, in duplicate) first with dichloromethane (DCM) $(150 \mathrm{~mL})$ for $24 \mathrm{~h}$ and then with $\mathrm{CH}_{3} \mathrm{OH}(150 \mathrm{~mL})$ for $48 \mathrm{~h}$. The extracts were concentrated in vacuo at $40{ }^{\circ} \mathrm{C}$ to give yield of $0.77 \%$ and $17.62 \%$ for the DCM and $\mathrm{CH}_{3} \mathrm{OH}$ extracts, respectively.

\section{Fourier transform infrared (FTIR) spectroscopic analysis}

The functional groups in the milled samples and extracts, and the extracted biomasses were determined by FTIR spectroscopy using a Nicolet iS5 spectrometer (ThermoScientific) using a ZnSe attenuated total reflection probe. Spectra were collected in duplicate. The absorbance spectra were baseline-corrected and averaged using Omnic v9.0 software (ThermoScientific). ${ }^{24,25}$

\section{ESI-MS experiment}

The samples (about $1.0 \mathrm{mg}$ each of DCM and $\mathrm{CH}_{3} \mathrm{OH}$ extracts, in duplicate) were added to $\mathrm{CH}_{3} \mathrm{OH}(1 \mathrm{~m}:)$ and acetic acid $(10 \mu \mathrm{L})$. The mixture was subjected to sonication to ensure total dissolution. Electrospray mass spectrometric analyses were performed on a 5989A device (Hewlett-Packard) equipped with an electrospray interface 59987A. Nitrogen was used as nebulizing gas, at a pressure of $50 \mathrm{psi}$ and a temperature of $300{ }^{\circ} \mathrm{C}$. Sample analysis was performed by direct infusion in ESI-MS using a syringe pump (Harvard Apparatus) at a flow-rate of $10 \mathrm{~mL} / \mathrm{min}$. Mass spectra were acquired in scan mode detection, and ESI-MS conditions were optimized using available standards.

\section{GC-MS of fatty acid methyl ester (FAME) derivatives}

Extracts (about $2.0 \mathrm{mg}$, in duplicate) were prepared by adding a solution $(2 \mathrm{~mL})$ of $\mathrm{CH}_{3} \mathrm{OH} / \mathrm{H}_{2} \mathrm{SO}_{4} / \mathrm{CHCl}_{3}(1.7: 0.3: 2.0 \mathrm{v} / \mathrm{v})$ in which the $\mathrm{CHCl}_{3}$ contained 1-naphthaleneacetic acid $(100 \mu \mathrm{g} /$ $\mathrm{mL}$ ) as an internal standard. The mixture was heated for $90 \mathrm{~min}$ at $90{ }^{\circ} \mathrm{C}$ in a sealed vial. Water was added to the mixture and the $\mathrm{CHCl}_{3}$ layer was removed, dried and transferred to a $\mathrm{GC}$ vial. The prepared FAME derivatives were analysed by electron impact ionization GC-MS on a Focus ISQ (ThermoScientific) with a ZB5 column $(30 \mathrm{~m} \times 0.25 \mathrm{~mm}$; Phenomenex $)$ and a temperature profile of $40{ }^{\circ} \mathrm{C}(1 \mathrm{~min})$ to $320^{\circ} \mathrm{C}(10 \mathrm{~min})$ at $5{ }^{\circ} \mathrm{C} / \mathrm{min}$. The eluted compounds were identified with authentic standards (C12 to $\mathrm{C} 20$ fatty acids) and by spectral matching with the NIST 2008 spectral library. 


\section{GC-MS of extracts for trimethylsilyl (TMS) derivatives}

Extracts (about $1.0 \mathrm{mg}$, in duplicate) were weighed in $\mathrm{GC}$ vials, to which $\mathrm{CH}_{2} \mathrm{Cl}_{2}(1 \mathrm{~mL})$ containing anthracene as an internal standard (IS; $50 \mu \mathrm{g} / \mathrm{mL}$ ) was added. The samples were silylated with addition of N,O-bis(trimethylsilyl)-trifluoro-acetamide (BSTFA) containing $1 \%$ trimethylchlorosilane (TMCS; $50 \mu \mathrm{L}$ ) and pyridine $(50 \mu \mathrm{L})$ and heated for $30 \mathrm{~min}$ at $70{ }^{\circ} \mathrm{C}$ or longer until the solution became clear. The prepared TMS derivatives were analysed by GC-MS (as described above).

\section{Analytical pyro (Py)-GC-MS of samples}

Analytical Py-GC-MS was carried out on the milled sample before and after extraction using a Pyrojector II (SGE Analytical Science) at $500{ }^{\circ} \mathrm{C}$ in He coupled to a GC-MS (FOCUS-ISQ; ThermoScientific) instrument operating in the electron impact ionization mode. The compounds were separated on the ZB5-MS capillary column (30 $\mathrm{mm} \times 0.25 \mathrm{~mm}$; Phenomenex) with temperature programmed to be $50{ }^{\circ} \mathrm{C}$ to $3000{ }^{\circ} \mathrm{C}$, at $5{ }^{\circ} \mathrm{C} \mathrm{min}^{-1}$. The eluted compounds were identified by their mass spectra, authentic standards, and with NIST 2008 library matching.

\section{High-performance liquid chromatography (HPLC) analysis}

Sugars were quantified by HPLC using a Rezex ROA column (7.8 $\mathrm{mm} \times 30 \mathrm{~cm}$; Phenomenex) and a Waters HPLC (Waters Corp.) equipped with differential refractive index detector (Shodex SE61; Showa Denko America, Inc.), on elution with $0.01 \mathrm{M} \mathrm{H}_{2} \mathrm{SO}_{4}(0.5$ $\mathrm{mL} / \mathrm{min})$ at $65^{\circ} \mathrm{C}$. The $\mathrm{CH}_{3} \mathrm{OH}$ extract $(10 \mathrm{mg})$ was dissolved in $0.01 \mathrm{M} \mathrm{H}_{2} \mathrm{SO}_{4}(5 \mathrm{~mL})$, centrifuged and the supernatant filtered $(0.45 \mu \mathrm{m})$. Data was acquired and analysed using the N2000 chromatography software (Science Technology Inc.). The sugar contents were determined from peak area using the external standard method with standard sugars (glucose, fructose, xylose, myo-inositol, sucrose, maltose and turanose).

\section{Isolation of chemical compounds}

The seeds $(2 \mathrm{~kg})$ were extracted with $\mathrm{CH}_{3} \mathrm{OH}$ and concentrated in vacuo to obtain $\mathrm{CH}_{3} \mathrm{OH}$ extract $(80 \mathrm{~g}, 4 \%$ yield). The crude extract was suspended in water and partitioned with $n$-hexane, ethyl acetate (EtOAc) and $n$-butanol to give respective fractions. The EtOAc fraction was subjected to Acelerated Gradient Chromatography (AGC) fractionation. Fractions 24 through 76 were bulked together and separated by column chromatography (silica gel 60-200 mesh) and elution was monitored by TLC. Fractions 36 through 67 were evaporated to yield a white crystalline solid (caffeine) with melting point of $230-233{ }^{\circ} \mathrm{C}$. Pooled AGC fractions 8 through 23 were concentrated and a yellow viscous solid was obtained, which was further purified by column chromatography, yielding a colourless solid (hexadecanoic acid) with minor impurities as accessed by TLC. Both compounds were characterized by NMR spectroscopy (400 MHz; Agilent).

\section{Antimicrobial assay}

The antimicrobial activity of $\mathrm{CH}_{3} \mathrm{OH}$ extract, solvent fractions and isolated caffeine were determined using the agar-well diffusion method. ${ }^{26,27}$ The bacteria were grown in a nutrient broth before
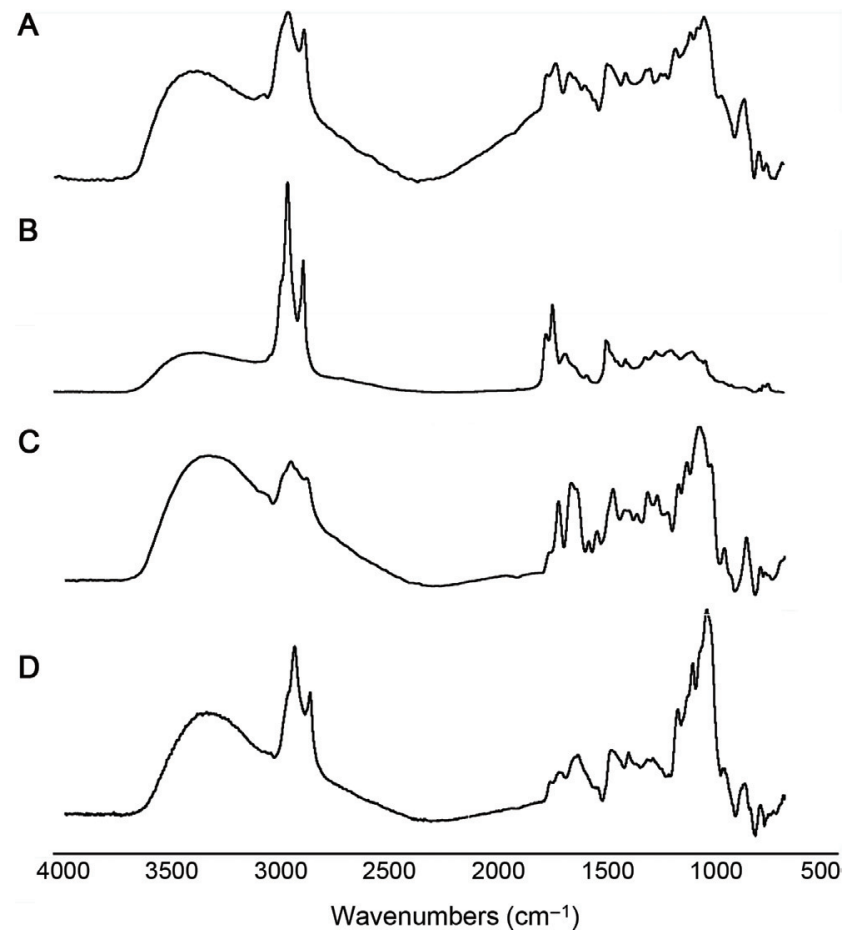

Fig. 1. Fourier transform infrared spectra of Cola nitida seed. (A) Powdered unextracted material, (B) Cola nitida dichloromethane (CND) extract, (C) Cola nitida methanol (CNM) extract, (D) Extracted biomass.

use, while the fungi were grown on potato dextrose agar medium until they sporulated, at which time they were harvested. The standardized bacteria suspension was spread on Muller-Hinton agar and allowed to set. Wells were then bored with a 6-mm borer and filled with the respective sample solutions at $10 \mathrm{mg} / \mathrm{mL}$, with ampicillin and nystatin added at $1 \mathrm{mg} / \mathrm{mL}$, which was followed by incubation at $37^{\circ} \mathrm{C}$ for $24 \mathrm{hrs}$. The fungal plates were incubated at $25^{\circ} \mathrm{C}$ for $96 \mathrm{hrs}$.

2,2-diphenyl-1-picrylhydrazyl (DPPH) radical scavenging antioxidant assay

Quantitative antioxidant activity was determined spectrophotometrically as described. ${ }^{28}$ Reactions were carried out in test tubes, and each of the solvent fractions and $\mathrm{CH}_{3} \mathrm{OH}$ extracts were tested at varying concentrations $(\mu \mathrm{g} / \mathrm{mL})$. Initial stock solutions of $1 \mathrm{mg} / \mathrm{mL}$ were prepared for the various plant extracts. The following final concentrations were prepared based on the preliminary qualitative TLC antioxidant screening: $60,30,15,7.5$, 3.75 and $1.875 \mu \mathrm{g} / \mathrm{mL}$ for the crude extract; $50,25,12.5,6.25$ and $3.13 \mu \mathrm{g} / \mathrm{mL}$ for n-butanol fraction; $30,15,7.5,3.75$ and 1.88 $\mu \mathrm{g} / \mathrm{mL}$ for the EtOAc fraction; and 2000, 1000, 500, 250, 125 and $62.5 \mu \mathrm{g} / \mathrm{mL}$ for the $\mathrm{n}$-hexane extract and caffeine from the stock solution. A $0.1 \mathrm{mM}$ DPPH radical solution in $\mathrm{CH}_{3} \mathrm{OH}(1 \mathrm{~mL})$ was added to $1 \mathrm{~mL}$ of the concentration series for each sample tested, in triplicate, and allowed to react at room temperature in the dark for $30 \mathrm{~min}$. The negative control was prepared by adding $0.1 \mathrm{mM}$ DPPH radical solution $(1 \mathrm{~mL})$ to $1 \mathrm{~mL}$ of methanol, in triplicate, and absorbance was measured at $517 \mathrm{~nm}$. The percentage antioxidant activity (\%AA) values of test samples were calculated from the absorbance using the formula: $\% \mathrm{AA}=\{$ Xcontrol-Xtest $\mathrm{Xcontrol}\} \times 100$ where Xcontrol is the absorbance of the negative control, Xtest is the absorbance of test samples concentrations. Ascorbic acid (vitamin C) was used as the standard antioxidant 

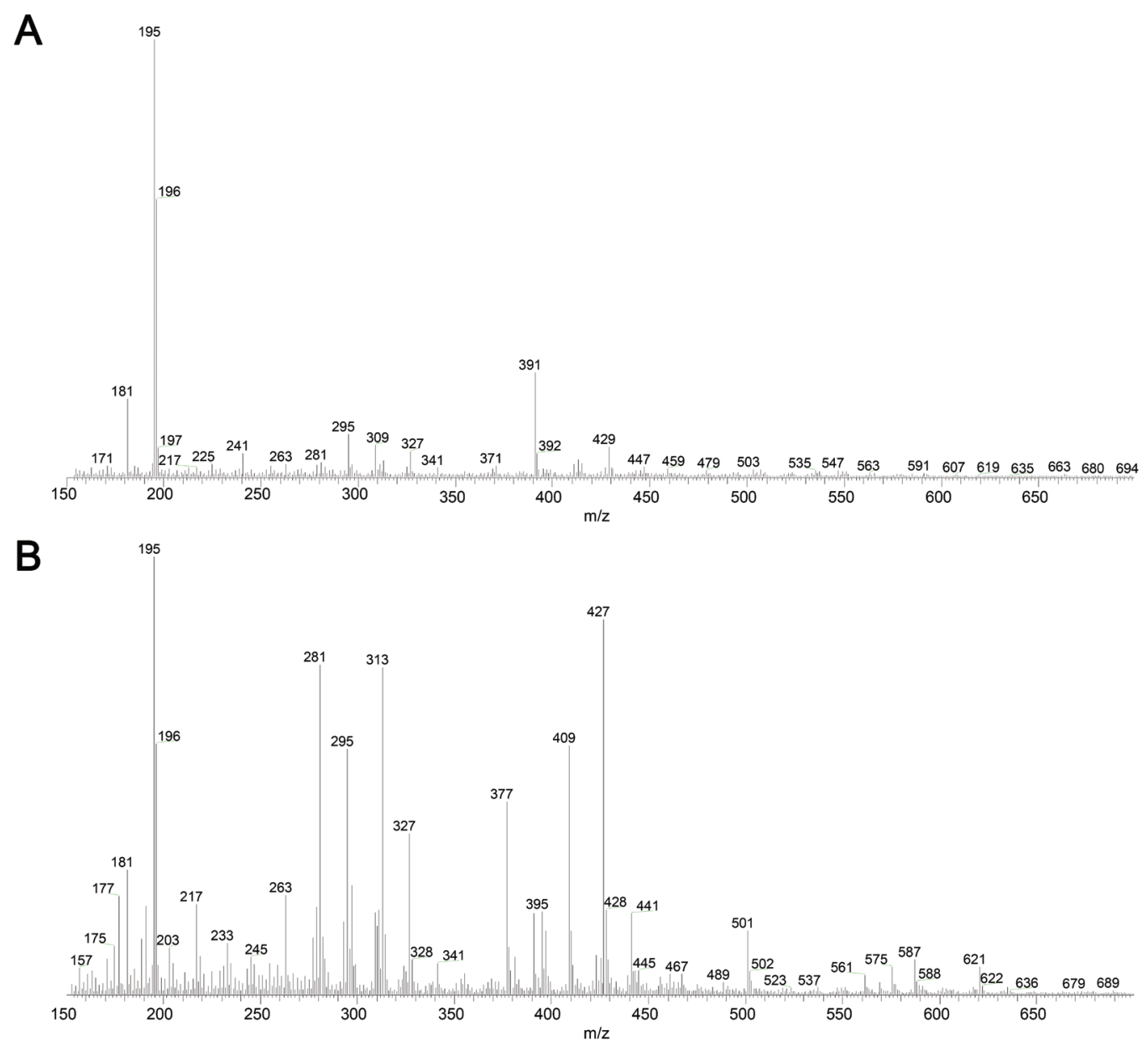

Fig. 2. Electrospray ionization mass spectra of Cola nitida extracts positive mode. (A) Cola nitida methanol extract, (B) Cola nitida dichloromethane extract.

agent.

The $\mathrm{IC}_{50}$ value (i.e. the concentration of the test samples leading to $50 \%$ reduction of the initial DPPH radical concentration) was calculated from the separate linear regression of plots of the mean percentage of antioxidant activity against the concentration of the test samples in $\mu \mathrm{g} / \mathrm{mL}$.

\section{Results and discussion}

\section{Extraction techniques}

Soxhlet extraction of the kola nut with $\mathrm{CH}_{2} \mathrm{Cl}_{2}$ and $\mathrm{CH}_{3} \mathrm{OH}$ afforded yields of $0.77 \%$ and $17.6 \%$, respectively. In comparison, large-scale cold extraction of the kola nut afforded a low yield of $4 \%$. Therefore, only the Soxhlet extracts were analysed in detail by a combination of GC-MS and ESI-MS. However, the batch $\mathrm{CH}_{3} \mathrm{OH}$ extract was used for antioxidant and antimicrobial assessment.

\section{FTIR spectroscopic analysis}

FTIR spectroscopy was used to investigate the functional groups in the sample and extracts. The spectra (Fig. 1) showed the presence of strong $\mathrm{O}-\mathrm{H}$ stretching vibration at $3340 \mathrm{~cm}^{-1}$ corresponding to hydroxyl groups in all, but quite pronounced in Figure 1A, $\mathrm{C}$, and $\mathrm{D}$. This band is less pronounced in Figure 1B, because the extract contained a majority of low polar compounds, whereas Figure 1C and D contained high polar phenolic compounds and lignocellulose respectively and containing multiple H-bonding. The absorption at just above $3000 \mathrm{~cm}^{-1}$ in Figure 1a is due to an aromatic $\mathrm{C}-\mathrm{H}$ stretch of polyphenols and aromatics; it is virtually absent in Figure $1 \mathrm{~b}$ but noticeable in Figure $1 \mathrm{C}$ and D. Similarly, the substituted aromatic $\mathrm{C}-\mathrm{H}$ bend band at $600-900 \mathrm{~cm}^{-1}$ is almost absent in Figure 1b but very conspicuous in Figure 1A, $\mathrm{C}$ and $\mathrm{D}$, indicating a low proportion of aromatics in the CND extract.

On the other hand, the $\mathrm{C}-\mathrm{H} \mathrm{sp} \mathrm{sp}^{3}$ stretching vibration, just below $3000 \mathrm{~cm}^{-1}$ and characteristic of long chain fatty acids $\left[-\left(\mathrm{CH}_{2}\right)\right.$ $\left.\mathrm{n}-\mathrm{CH}_{3}\right]$, is more conspicuously prominent in Figure 1B than in Figure $1 \mathrm{C}$ and D. Carbonyl stretching absorption of carboxylic acid aldehydes and ketones is very low in Figure 1D, as most carbonyl compounds had already been removed through the process of extraction. The absorption band at $1000-1200 \mathrm{~cm}^{-1}$ that was due to $\mathrm{C}-\mathrm{O}$ stretch of esters (glycosides and cellulose) was most intense in Figure 1C and D but low in Figure 1B. These data show that FTIR can be used to monitor and assess the effectiveness of the extraction process, apart from facilitating quantitative evalu- 


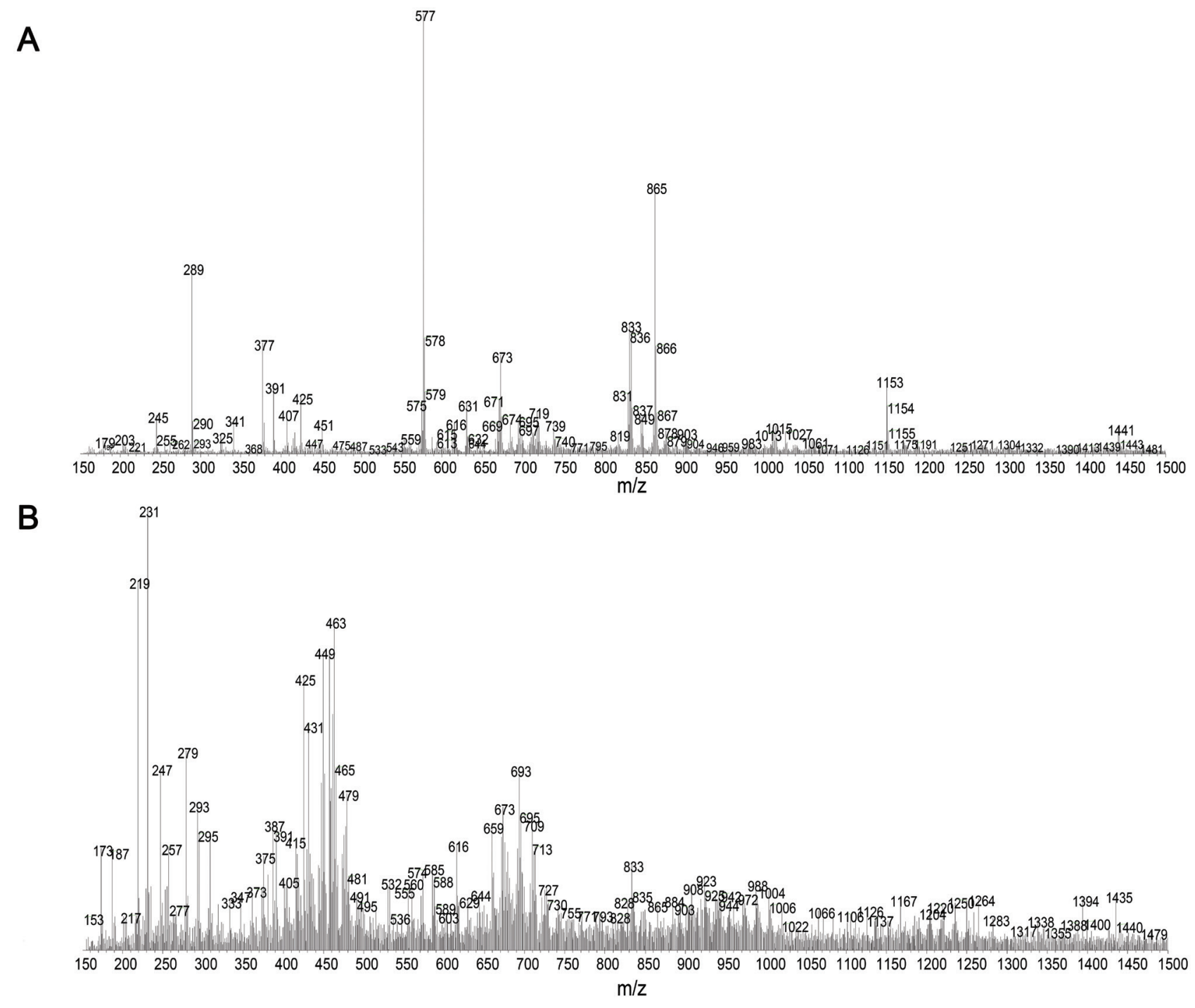

Fig. 3. Electrospray ionization mass spectra of Cola nitida extracts negative mode. (a) Cola nitida methanol extract, (b) Cola nitida dichloromethane extract.

ations.

\section{Electrospray mass spectrometric analysis of extracts}

ESI-MS is a powerful analytical tool to rapidly analyse extracts and isolated fractions without chromatographic separation. ${ }^{29-31}$ Moreover, ESI-MS makes it possible to discriminate between various flavonoid classes, provide information on the glycosylation position and characterize saponins. ${ }^{32-34}$ Therefore, ESI-MS was employed to directly analyse the $\mathrm{CH}_{2} \mathrm{Cl}_{2}$ and $\mathrm{CH}_{3} \mathrm{OH}$ extracts in positive (Fig. 2) and negative (Fig. 3) ion modes.

The positive ion ESI-MS for both extracts showed the largest peak at $\mathrm{m} / \mathrm{z} 195$ (100\% intensity), which was due to caffeine $\left([\mathrm{M}+\mathrm{H}]^{+}\right)$. In the $\mathrm{MeOH}$ extract (Fig. 2A), the tentative peak assignments are as follows: $181\left([\mathrm{M}+\mathrm{H}]^{+}\right.$, theobromine); 295 (unknown); and 391 (unknown). For the $\mathrm{CH}_{2} \mathrm{Cl}_{2}$ extract (Fig. 2B), the tentative peak assignments are: $193\left([\mathrm{M}+\mathrm{H}]^{+}\right.$, quinic acid $) ; 313\left([\mathrm{M}+\mathrm{Na}]^{+}\right.$, catechin), $355\left([\mathrm{M}+\mathrm{H}]^{+}\right.$, chlorogenic acid); and m/z 281, 294, 377 and 426 (unknowns). The negative ion ESI-MS for both extracts
(Fig. 3) showed a multitude of peaks. For the $\mathrm{CH}_{3} \mathrm{OH}$ extract (Fig. $3 \mathrm{~A})$, the tentative assignments are: $\mathrm{m} / \mathrm{z} 289\left([\mathrm{M}-\mathrm{H}]^{-}\right.$, catechin); $\mathrm{m} / \mathrm{z} 577$ and 578 (procyanidins B1, B2 [oligomeric catechins] and naringin flavonoids); and m/z 1153 and 1154 (proanthocyanidins). There were many unidentified peaks. Niemenak et al. ${ }^{6}$ also reported that HPLC of Cola nitida extract had 11 unidentified compounds.

\section{GC-MS of extracts of FAME derivatives}

It is well known that fatty acids (FAs), especially the essential fatty acids (EFAs), are important for optimal functioning of the body. They regulate such bodily functions as heart rate, blood pressure, blood clotting and fertility. They also participate in immune system inflammation against harmful waste products. Balance of EFAs is important for good health and normal development of humans. ${ }^{35,36}$ FAs occur widely in natural fats and dietary oils and they play important roles as nutritious substances and metabolites in living organisms.$^{37}$ With these important biological activities of FAs, those present in the extracts as free or glycerides were con- 
Table 1. GC-MS FAME derivatives of CND extract

\begin{tabular}{|c|c|c|c|c|c|c|}
\hline S/No & Compound & Molecular formula & Class & $\begin{array}{l}\text { Molecular } \\
\text { weight }\end{array}$ & $\begin{array}{l}\text { Retention } \\
\text { time (min) }\end{array}$ & \% Extract \\
\hline 1 & Naphthalene acetic acid (IS) & $\mathrm{C}_{13} \mathrm{H}_{12} \mathrm{O}_{2}$ & & 200 & 27.34 & \\
\hline 2 & Caffeine & $\mathrm{C}_{8} \mathrm{H}_{10} \mathrm{~N}_{4} \mathrm{O}_{2}$ & Alkaloid & 194 & 30.43 & 1.7 \\
\hline 3 & Palmitic acid & $\mathrm{C}_{17} \mathrm{H}_{34} \mathrm{O}_{2}$ & FA & 270 & 31.83 & 19.4 \\
\hline 4 & Linoleic acid & $\mathrm{C}_{19} \mathrm{H}_{34} \mathrm{O}_{2}$ & FA & 294 & 35 & 8.6 \\
\hline 5 & Oleic acid & $\mathrm{C}_{19} \mathrm{H}_{36} \mathrm{O}_{2}$ & FA & 296 & 35.11 & 24.0 \\
\hline 6 & Stearic acid & $\mathrm{C}_{19} \mathrm{H}_{38} \mathrm{O}_{2}$ & FA & 298 & 35.6 & 1.5 \\
\hline 7 & 8,9-Methylene-8-heptadecenoic acid & $\mathrm{C}_{19} \mathrm{H}_{34} \mathrm{O}_{2}$ & FA & 294 & 36.24 & 4.9 \\
\hline 8 & 10,12-Octadecadienoic acid & $\mathrm{C}_{19} \mathrm{H}_{34} \mathrm{O}_{2}$ & FA & 294 & 36.39 & 1.7 \\
\hline 9 & 7-(Tetrahydro-2H-pyran-2-yloxy)-2-octyn-1-ol & $\mathrm{C}_{13} \mathrm{H}_{22} \mathrm{O}_{3}$ & Alcohol & 226 & 36.63 & 1.3 \\
\hline 10 & 2-Octylcyclopropene-1-heptanol & $\mathrm{C}_{18} \mathrm{H}_{34} \mathrm{O}$ & Alcohol & 266 & 36.79 & 1.7 \\
\hline 11 & 8-Oxohexadecanoic acid & $\mathrm{C}_{17} \mathrm{H}_{32} \mathrm{O}_{3}$ & FA & 284 & 37.25 & 12.0 \\
\hline 12 & Tetrahydropyran-2-yl ether of 7-dodecynol & $\mathrm{C}_{17} \mathrm{H}_{30} \mathrm{O}_{2}$ & Alcohol & 266 & 37.46 & 1.2 \\
\hline 13 & 9,10-Methylene-9-octadecenoic acid & $\mathrm{C}_{20} \mathrm{H}_{36} \mathrm{O}_{2}$ & FA & 308 & 37.99 & 1.4 \\
\hline 14 & 1-Ethyl-(1,1-dimethylethyl)-methoxycyclohexan-1-ol & $\mathrm{C}_{13} \mathrm{H}_{26} \mathrm{O}_{2}$ & Alcohol & 214 & 38.97 & 3.2 \\
\hline 15 & Stigmastan-3,5-diene & $\mathrm{C}_{29} \mathrm{H}_{48}$ & Sterol & 396 & 50.12 & 0.2 \\
\hline 16 & Sitosterol acetate & $\mathrm{C}_{31} \mathrm{H}_{52} \mathrm{O}_{2}$ & Sterol & 456 & 52.16 & 0.7 \\
\hline 17 & Sitosterol & $\mathrm{C}_{29} \mathrm{H}_{50} \mathrm{O}$ & Sterol & 414 & 52.86 & 0.6 \\
\hline
\end{tabular}

verted to FAME derivatives for identification and quantification.

The $\mathrm{CH}_{2} \mathrm{Cl}_{2}$ and $\mathrm{CH}_{3} \mathrm{OH}$ extracts were derivatised into FAME and analysed by GC-MS. The $\mathrm{CH}_{2} \mathrm{Cl}_{2}$ extract contained FAs ranging from $\mathrm{C} 16$ to $\mathrm{C} 19$. Palmitic acid (C16: $0.447 \mathrm{mg} / \mathrm{g}$ ), linoleic acid (C18: $0.198 \mathrm{mg} / \mathrm{g})$, oleic acid (C18: $0.553 \mathrm{mg} / \mathrm{g})$, stearic acid (C18: 0.034mg/g), 8,9-methylene-heptadec-8-oic acid (C18: 0.112 $\mathrm{mg} / \mathrm{g}), 10,12$-octadecadienoic acid (C18: $0.040 \mathrm{mg} / \mathrm{g}$ ), 8-oxohexadecanoic acid (C16: $0.275 \mathrm{mg} / \mathrm{g}$ ) and 9,10-methylene-octadec9-oic acid (C19: $0.032 \mathrm{mg} / \mathrm{g}$ ) were the major FAs detected. The FAs constitute about $73 \%$ of the extract. Furthermore, caffeine, fatty alcohols and sterols were also detected (Table 1). The $\mathrm{CH}_{3} \mathrm{OH}$ extract did not contain any FAs, only caffeine.

\section{GC-MS of extracts of TMS derivatives}

Trimethylsilylating reagent is routinely used to derivatise rather non-volatile compounds, such as certain alcohols, phenols, or carboxylic acids, by substituting a TMS group for a hydrogen in the hydroxyl groups on the compounds. Both extracts were derivatised to TMS ethers/esters to conduct the analyses for non-polar and polar components using GC-MS. The results for the $\mathrm{CH}_{2} \mathrm{Cl}_{2}$ and $\mathrm{CH}_{3} \mathrm{OH}$ extracts as their TMS derivatives are given in Tables 2 and 3.

Caffeine $\left(17.9 \%\right.$ and $3.85 \%$ in $\mathrm{CH}_{3} \mathrm{OH}$ and $\mathrm{CH}_{2} \mathrm{Cl}_{2}$ extracts, respectively) was predominant, as observed by Niemenak et al. ${ }^{6}$ Catechin was the dominant flavonoid in the kola seed. Other identified constituents of $\mathrm{CH}_{3} \mathrm{OH}$ extract included: sugars (45\%); catechin (13\%); malic acid and glycerol (Table 2). The presence of glucose, fructose and sucrose in the $\mathrm{CH}_{3} \mathrm{OH}$ extract was detected by both GC-MS and HPLC analyses. The $\mathrm{CH}_{2} \mathrm{Cl}_{2}$ extract consist mainly of FFAs (Table 3), and this observation is consistent with the results of FAME analysis. Other compounds found in this extract were alkaloids and sterols.

Table 2. GC-MS of Cola nitida $\mathrm{CH}_{3} \mathrm{OH}$ extracts of TMS derivatives

\begin{tabular}{llllll}
\hline Compound & Molecular formula & Class & Molecular weight & Retention time (min) & \% Extract \\
\hline Glycerol TMS & $\mathrm{C}_{12} \mathrm{H}_{32} \mathrm{O}_{3} \mathrm{Si}_{3}$ & Alcohol & 308 & 18.11 & 0.2 \\
Malic acid TMS & $\mathrm{C}_{13} \mathrm{H}_{30} \mathrm{O}_{5} \mathrm{Si}_{3}$ & Acid & 350 & 23.65 & 1.5 \\
Anthracene (IS) & $\mathrm{C}_{14} \mathrm{H}_{10}$ & & 178 & 30.14 & 2.2 \\
Fructose $\mathrm{TMS}_{5}$ & $\mathrm{C}_{19} \mathrm{H}_{46} \mathrm{O}_{6} \mathrm{Si}_{4}$ & Sugar & 540 & 30.70 & 17.9 \\
Caffeine & $\mathrm{C}_{8} \mathrm{H}_{10} \mathrm{~N}_{4} \mathrm{O}_{2}$ & Alkaloid & 194 & 31.23 & 0.7 \\
Glucose-TMS-5 & $\mathrm{C}_{21} \mathrm{H}_{52} \mathrm{O}_{6} \mathrm{Si}_{5}$ & Sugar & 540 & 32.77 & 2.9 \\
D-Turanose-TMS-7 & $\mathrm{C}_{33} \mathrm{H}_{78} \mathrm{O}_{11} \mathrm{Si}_{7}$ & Sugar & 846 & 45.65 & 39.5 \\
Sucrose-TMS & $\mathrm{C}_{36} \mathrm{H}_{86} \mathrm{O}_{11} \mathrm{Si}_{8}$ & Sugar & 918 & 45.75 & 12.9 \\
Catechin-TMS-5 & $\mathrm{C}_{30} \mathrm{H}_{54} \mathrm{O}_{6} \mathrm{Si}_{5}$ & Flavonoid & 650 & 48.74 & \\
\hline
\end{tabular}


Table 3. GC-MS of Cola nitida $\mathrm{CH}_{2} \mathrm{Cl}_{2}$ extracts of TMS derivatives

\begin{tabular}{llllll}
\hline Compound & Molecular formula & Class & Molecular weight & Retention time (min) & \% Extract \\
\hline Nonanoic acid TMS & $\mathrm{C}_{12} \mathrm{H}_{26} \mathrm{O}_{2} \mathrm{Si}$ & FA & 230 & 20.14 & 0.82 \\
Octanedioic acid TMS & $\mathrm{C}_{14} \mathrm{H}_{30} \mathrm{O}_{4} \mathrm{Si}_{2}$ & FA & 318 & 28.27 & 0.26 \\
Anthracene & $\mathrm{C}_{14} \mathrm{H}_{10}$ & & 178 & 30.14 & 31.32 \\
Caffeine & $\mathrm{C}_{8} \mathrm{H}_{10} \mathrm{~N}_{4} \mathrm{O}_{2}$ & Alkaloid & 194 & 35.07 & 2.95 \\
Palmitic acid TMS & $\mathrm{C}_{19} \mathrm{H}_{40} \mathrm{O}_{2} \mathrm{Si}$ & FA & 328 & 37.94 & 1.64 \\
Linoleic acid TMS & $\mathrm{C}_{21} \mathrm{H}_{40} \mathrm{O}_{2} \mathrm{Si}$ & FA & 352 & 38.11 & 5.95 \\
Oleic acid TMS & $\mathrm{C}_{21} \mathrm{H}_{42} \mathrm{O}_{2} \mathrm{Si}$ & FA & 354 & 38.58 & 1.89 \\
Stearic acid TMS & $\mathrm{C}_{21} \mathrm{H}_{44} \mathrm{O}_{2} \mathrm{Si}$ & FA & 356 & 39.57 & 0.14 \\
Linolenic acid TMS & $\mathrm{C}_{21} \mathrm{H}_{38} \mathrm{O}_{2} \mathrm{Si}$ & FA & 350 & 53.46 & 1.08 \\
Stigmasterol TMS & $\mathrm{C}_{32} \mathrm{H}_{56} \mathrm{OSi}$ & Sterol & 484 & 54.13 & 0.20 \\
Sitosterol TMS & $\mathrm{C}_{32} \mathrm{H}_{58} \mathrm{OSi}$ & Sterol & 486 & 2.05 \\
\hline
\end{tabular}

\section{Analytical Py-GC-MS of samples}

Direct analysis of the kola nut and extracted nut were performed by analytical Py-GC-MS. The identities of the products are given in Table 4. The main compounds in the kola nut were caffeine $(22.5 \%), \mathrm{CO}_{2}(12.8 \%)$, methyl acetate $(6.3 \%)$, acetic formic anhydride $(5.9 \%)$, levoglucosan $(5.4 \%)$, N-methyl ethylamine $(4.9 \%)$, 1,2-cyclopentanedione (3.4\%) and pyrocatechol (3.0\%). Aliphatic and heterocyclic (pyrolidine, alstonine and xanthenes) amines were identified. This finding is in accordance with the report by Atawodi et al. ${ }^{9}$ Py-GC-MS of the extracted kola nut showed the presence of 22 compounds (Table 4). The main compounds identified were: $\mathrm{CO}_{2}(17 \%)$, acetol (11\%), 1,2-benzenediol (11\%), 1,2-cyclopentanedione (10\%), acetic acid (7\%), butylamine $(5 \%)$ and caffeine $(5 \%)$.

It is noteworthy that alkanes, alkenes ethers and steroids/sterols were not identified by the Py-GC-MS of the extracted biomass; this may be explained as due to exhaustive removal of the relatively low polar compounds during the process of extraction. Analytical pyrolysis experiment showed caffeine as the major constituent of Cola nitida. Maltol, a naturally occurring organic compound, is primarily used as a flavour enhancer. ${ }^{10}$ Its presence in the Cola nitida seed may be contributory to the application of the seed in the manufacture of soft drinks. ${ }^{3-5}$

\section{Structure elucidation}

Compound 1 (caffeine) was obtained as a white crystalline solid, with a melting point of $230-233{ }^{\circ} \mathrm{C} .{ }^{1} \mathrm{HNMR}\left(400 \mathrm{MHz}, \mathrm{CDCl}_{3}\right.$, $\delta$ ppm): $7.46(1 \mathrm{Hs}, 8 \mathrm{H}), 3.95,3.54,3.36$ (s, $3 \mathrm{H}$ at $1,3,7) .{ }^{13} \mathrm{CNMR}$ $\left(100 \mathrm{MHz}, \mathrm{CDCl}_{3}, \delta \mathrm{ppm}\right): 155.3$ and 151.6 (C6 and $\mathrm{C} 2$ respectively), 148.6, 141.5, 107.5 (olefinic C8, C4 and C5), 33.5, 29.7 and 27.9 (methyl groups). These correlate with the literature data for caffeine.

Compound 2 (n-Hexadecanoic acid): ${ }^{1} \mathrm{HNMR}\left(400 \mathrm{MHz} \mathrm{CDCl}_{3}\right.$, $\delta \mathrm{ppm}): 2.24-1.21\left(\mathrm{CH}_{2}\right.$ protons $), 0.78\left(\mathrm{CH}_{3}\right.$ protons $) .{ }^{13} \mathrm{CNMR}$ (100 MHz, $\left.\mathrm{CDCl}_{3}, \delta \mathrm{ppm}\right): 179(\mathrm{C}=\mathrm{O}) ; 34.15-22.64\left(\mathrm{CH}_{2}\right.$ carbon atoms); $15.02 \mathrm{CH}_{3}$ group.

\section{Antimicrobial activity}

The kola nut $\mathrm{CH}_{3} \mathrm{OH}$ extract and fractions, and isolated caffeine showed varying degrees of inhibitory activities against the tested bacterial and fungal strains (Fig. 4 and Supplementary Table S1). Their activity was more pronounced against Gram-positive bacteria than Gram-negative bacteria. This could be a result of the morphological differences between these microorganisms. The Grampositive bacteria have an outer peptidoglycan layer, which is not an effective permeability barrier, making these microorganisms more susceptible to the compounds under investigation; meanwhile, the Gram-negative bacteria have an outer phospholipidic membrane that contains LPSs, making the cell wall of these microorganisms impermeable. ${ }^{38-40 .}$

These microorganisms are implicated in the pathogenesis of human infections. The result obtained showed the EtOAc fraction as having the highest antimicrobial activity against most of the organisms compared to other fractions. However, the EtOAc fraction was not active against Pseudomonas Spp., Clostridium sporogenes, Corynebacterium pyogenes, Shigella Spp. and Candida albicans. The activity of the extract indicated $\mathrm{CH}_{3} \mathrm{OH}$ as a good solvent for preparation of extracts for antimicrobial assay. ${ }^{41,42}$ The antimicrobial activity of the $\mathrm{CH}_{3} \mathrm{OH}$ extract can be attributed to synergistic effect of compounds in the extract. Isolated caffeine (compound 1) demonstrated higher activity than n-butanol against Bacillus Spp., Escherichia coli and Aspergillus niger. Extract and fractions did not show activity against Shigella Spp. Caffeine demonstrated appreciable antimicrobial activity against Bacillus cereus, Escherichia coli, Pseudomonas vulgaris and the fungi.

\section{Antioxidant activity}

The DPPH radical antioxidant activity showed the ability of the kola nut $\mathrm{CH}_{3} \mathrm{OH}$ extracts and fractions, and isolated caffeine to reduce DPPH radicals through the transfer of acidic labile protons by a free radical mechanism. None of the extracts compares significantly with that of ascorbic acid. However, the EtOAc and butanol fractions exhibited good DPPH antioxidant activity. The $\mathrm{IC}_{50}$ values decreased in this order: ascorbic acid $(3.2 \pm 0.05 \mu \mathrm{g} / \mathrm{mL})$, butanol extract $(9.8 \pm 0.5 \mu \mathrm{g} / \mathrm{mL})$, EtOAc extract $(15.1 \pm 0.7 \mu \mathrm{g} /$ $\mathrm{mL}), \mathrm{CH}_{3} \mathrm{OH}$ extract $(22.7 \pm 1.7 \mu \mathrm{g} / \mathrm{mL})$, hexane extract $(321 \pm 7$ $\mu \mathrm{g} / \mathrm{mL})$ and caffeine $(1370 \pm 19 \mu \mathrm{g} / \mathrm{mL})$.

\section{Future research direction}

A number of chemical compounds have been reported from the 
Table 4. Py-GC-MS of unextracted and extracted powdered Cola nitida seed

\begin{tabular}{|c|c|c|c|c|c|}
\hline Compound & $\begin{array}{l}\text { Molecular } \\
\text { formula }\end{array}$ & $\begin{array}{l}\text { Molecular } \\
\text { weight }\end{array}$ & $\begin{array}{l}\text { Retention } \\
\text { time (min) }\end{array}$ & $\begin{array}{l}\text { Kola } \\
\text { nut, \% }\end{array}$ & $\begin{array}{l}\text { Extracted } \\
\text { nut, \% }\end{array}$ \\
\hline $\mathrm{CO}_{2}$ & $\mathrm{CO}_{2}$ & 44 & 1.12 & 12.8 & 17.4 \\
\hline N-Methyl ethylamine & $\mathrm{C}_{3} \mathrm{H}_{9} \mathrm{~N}$ & 59 & 1.30 & 4.9 & \\
\hline Butylamine & $\mathrm{C}_{4} \mathrm{H}_{11} \mathrm{~N}$ & 72 & 1.38 & & 4.9 \\
\hline Acetic acid & $\mathrm{C}_{3} \mathrm{H}_{4} \mathrm{O}_{3}$ & 60 & 1.64 & 5.9 & 6.5 \\
\hline Pentanone & $\mathrm{C}_{5} \mathrm{H}_{10} \mathrm{O}$ & 86 & 1.65 & & 4.6 \\
\hline Acetol & $\mathrm{C}_{3} \mathrm{H}_{6} \mathrm{O}_{2}$ & 74 & 1.97 & 6.3 & 11.3 \\
\hline Unknown & & 92 & 3.17 & 1.5 & \\
\hline Butanedial & $\mathrm{C}_{4} \mathrm{H}_{6} \mathrm{O}_{2}$ & 86 & 3.36 & 1.7 & 3.4 \\
\hline Methyl pyruvate & $\mathrm{C}_{4} \mathrm{H}_{6} \mathrm{O}_{3}$ & 102 & 3.49 & 1.7 & 1.1 \\
\hline Butanedial & $\mathrm{C}_{4} \mathrm{H}_{6} \mathrm{O}_{2}$ & 86 & 3.63 & & 2.7 \\
\hline Unknown & $\mathrm{C}_{4} \mathrm{H}_{4} \mathrm{O}_{2}$ & 84 & 3.66 & 1.0 & 1.1 \\
\hline 2-Oxo-3-cyclopentene-1-acetaldehyde? & $\mathrm{C}_{7} \mathrm{H}_{8} \mathrm{O}_{2}$ & 124 & 4.37 & 1.3 & 3.2 \\
\hline 2-Furfuryl alcohol & $\mathrm{C}_{5} \mathrm{H}_{6} \mathrm{O}_{2}$ & 98 & 4.90 & 2.2 & 4.4 \\
\hline Unknown & $\mathrm{C}_{5} \mathrm{H}_{8} \mathrm{O}_{3}$ & 116 & 5.16 & 1.1 & \\
\hline 2(5H)-Furanone & $\mathrm{C}_{4} \mathrm{H}_{4} \mathrm{O}_{2}$ & 84 & 6.34 & 2.1 & 3.9 \\
\hline 1,2-Cyclopentanedione & $\mathrm{C}_{5} \mathrm{H}_{6} \mathrm{O}_{2}$ & 98 & 6.67 & 3.4 & 9.9 \\
\hline 1-Methyl-1-cyclopenten-3-one & $\mathrm{C}_{6} \mathrm{H}_{8} \mathrm{O}$ & 96 & 7.85 & & 1.3 \\
\hline 4-Methyl-5H-furan-2-one + Unknown & $\mathrm{C}_{5} \mathrm{H}_{6} \mathrm{O}_{2}$ & $98+110$ & 8.09 & & 0.6 \\
\hline Phenol & $\mathrm{C}_{6} \mathrm{H}_{6} \mathrm{O}$ & 94 & 8.28 & & $x X$ \\
\hline 2 Hydroxy-3-methyl-2-cyclopenten-1-one & $\mathrm{C}_{6} \mathrm{H}_{8} \mathrm{O}_{2}$ & 112 & 9.54 & 1.4 & 5.4 \\
\hline 2,3 Dimethyl-2-cyclopenten-1-one & $\mathrm{C}_{7} \mathrm{H}_{10} \mathrm{O}$ & 110 & 9.85 & 0.3 & \\
\hline Unknown & & 116 & 10.00 & 0.8 & \\
\hline 2-Methyl phenol & $\mathrm{C}_{7} \mathrm{H}_{8} \mathrm{O}_{2}$ & 108 & 10.40 & 0.7 & \\
\hline 3-Methyl-phenol & $\mathrm{C}_{7} \mathrm{H}_{8} \mathrm{O}_{2}$ & 108 & 10.99 & 0.7 & \\
\hline Unknown & & $57 ?$ & 11.51 & 1.9 & 0.9 \\
\hline 3 Hydroxy-2-methyl-4H-pyran-4-one (Maltol) & $\mathrm{C}_{6} \mathrm{H}_{6} \mathrm{O}_{3}$ & 126 & 12.03 & 0.5 & 0.7 \\
\hline 3-Ethyl-2-hydroxy-2-cyclopenten-1-one & $\mathrm{C}_{7} \mathrm{H}_{10} \mathrm{O}_{2}$ & 126 & 12.21 & 0.4 & 1.5 \\
\hline 4-Hydroxy-3-methyl-(5H)-furanone or 3-methyl-2,4(3H,5H)-furandione & $\mathrm{C}_{5} \mathrm{H}_{6} \mathrm{O}_{3}$ & 114 & 12.33 & 0.5 & \\
\hline Dihydro-2H-pyran-3(4H)-one + unknown & $\mathrm{C}_{5} \mathrm{H}_{8} \mathrm{O}_{2}$ & $100+128$ & 13.16 & 0.8 & \\
\hline Ethyl/dimethyl phenol + 3,5-dihydroxy-2-methyl-(4H)-pyran-4-one & $\mathrm{C}_{11} \mathrm{H}_{18} \mathrm{O}_{7}$ & $122+142$ & 13.66 & 0.7 & \\
\hline Benzene diol + 3,5 dihydroxy-2 methyl-4-pyrone & $\mathrm{C}_{6} \mathrm{H}_{6} \mathrm{O}_{2}+\mathrm{C}_{6} \mathrm{H}_{6} \mathrm{O}_{4}$ & $110+142$ & 14.13 & 0.7 & \\
\hline 5-Hydroxymethyldihydrofuran-2-one & $\mathrm{C}_{5} \mathrm{H}_{8} \mathrm{O}_{3}$ & 116 & 14.42 & 0.8 & \\
\hline 1,2-Benzenediol & $\mathrm{C}_{6} \mathrm{H}_{6} \mathrm{O}_{2}$ & 110 & 14.67 & 3.1 & 11.3 \\
\hline 1,4:3,6-Dianhydro-hexose & $\mathrm{C}_{6} \mathrm{H}_{8} \mathrm{O}_{4}$ & 144 & 14.86 & 1.0 & 1.9 \\
\hline Coumaran & $\mathrm{C}_{8} \mathrm{H}_{8} \mathrm{O}$ & 120 & 15.13 & 0.5 & \\
\hline 5 Hydroxymethyl-2-furaldehyde & $\mathrm{C}_{6} \mathrm{H}_{6} \mathrm{O}_{3}$ & 126 & 15.47 & 0.6 & \\
\hline 4-Methyl catechol & $\mathrm{C}_{7} \mathrm{H}_{8} \mathrm{O}_{2}$ & 124 & 17.21 & 1.5 & 2.0 \\
\hline Syringol & $\mathrm{C}_{8} \mathrm{H}_{10} \mathrm{O}_{3}$ & 154 & 18.69 & 0.5 & \\
\hline Levoglucosan & $\mathrm{C}_{6} \mathrm{H}_{10} \mathrm{O}_{5}$ & 162 & 22.80 & 5.4 & \\
\hline Caffeine & $\mathrm{C}_{8} \mathrm{H}_{10} \mathrm{~N}_{4} \mathrm{O}_{2}$ & 194 & 30.36 & 22.3 & 5.2 \\
\hline Theobromine & $\mathrm{C}_{7} \mathrm{H}_{8} \mathrm{~N}_{4} \mathrm{O}_{2}$ & 180 & 30.75 & 1.8 & 1.0 \\
\hline
\end{tabular}


Table 4. Py-GC-MS of unextracted and extracted powdered Cola nitida seed - (continued)

\begin{tabular}{|c|c|c|c|c|c|}
\hline Compound & $\begin{array}{l}\text { Molecular } \\
\text { formula }\end{array}$ & $\begin{array}{l}\text { Molecular } \\
\text { weight }\end{array}$ & $\begin{array}{l}\text { Retention } \\
\text { time (min) }\end{array}$ & $\begin{array}{l}\text { Kola } \\
\text { nut, \% }\end{array}$ & $\begin{array}{l}\text { Extracted } \\
\text { nut, \% }\end{array}$ \\
\hline Palmitic acid & $\mathrm{C}_{16} \mathrm{H}_{32} \mathrm{O}_{2}$ & 256 & 32.36 & 1.5 & 0.8 \\
\hline Linoleic acid & $\mathrm{C}_{18} \mathrm{H}_{32} \mathrm{O}_{2}$ & 280 & 35.44 & 1.0 & \\
\hline Oleic acid & $\mathrm{C}_{18} \mathrm{H}_{34} \mathrm{O}_{2}$ & 282 & 35.62 & 0.9 & 0.5 \\
\hline Stearic acid & $\mathrm{C}_{18} \mathrm{H}_{36} \mathrm{O}_{2}$ & 284 & 36.01 & 0.3 & \\
\hline C18:2 & $\mathrm{C}_{18} \mathrm{H}_{32} \mathrm{O}_{2}$ & 280 & 36.67 & 0.3 & \\
\hline C19:2 & $\mathrm{C}_{19} \mathrm{H}_{34} \mathrm{O}_{2}$ & 294 & 37.16 & 0.4 & \\
\hline Methyl-2,3-dicyano-3- [4-dimethylamino)phenyl]-2-propenoate & $\mathrm{C}_{14} \mathrm{H}_{13} \mathrm{~N}_{3} \mathrm{O}_{2}$ & 255 & 43.57 & & 0.6 \\
\hline Squalene & $\mathrm{C}_{30} \mathrm{H}_{50}$ & 410 & 46.34 & 0.4 & \\
\hline Cholestadiene & $\mathrm{C}_{27} \mathrm{H}_{44}$ & 368 & 47.28 & 0.1 & \\
\hline Unknown steroid & & 344 & 47.50 & 0.1 & \\
\hline Stigmastan-3,5-diene & $\mathrm{C}_{29} \mathrm{H}_{48}$ & 396 & 49.89 & 0.3 & \\
\hline Nortrachelogenin & $\mathrm{C}_{20} \mathrm{H}_{22} \mathrm{O}_{7}$ & 374 & 50.77 & 0.2 & \\
\hline 6,9,10-Trimethoxy-12H-[1]benzopino[2,3,4-ij]isoquinoline (oxocularine) & $\mathrm{C}_{19} \mathrm{H}_{17} \mathrm{NO}_{4}$ & 323 & 51.17 & 0.4 & \\
\hline 6,16 Dimethylpregna-1,4,6-triene-3,20-dione & $\mathrm{C}_{23} \mathrm{H}_{30} \mathrm{O}_{2}$ & 338 & 51.58 & 0.3 & \\
\hline Stigmasterol & $\mathrm{C}_{29} \mathrm{H}_{48} \mathrm{O}$ & 412 & 51.94 & 0.2 & \\
\hline 3,4,5,6-Tetrahydro alstonine & $\mathrm{C}_{21} \mathrm{H}_{24} \mathrm{~N}_{2} \mathrm{O}_{3}$ & 352 & 52.26 & 0.4 & \\
\hline Sitosterol & $\mathrm{C}_{29} \mathrm{H}_{50} \mathrm{O}$ & 414 & 52.67 & 0.5 & \\
\hline
\end{tabular}

seed of Cola nitida; however, current findings revealed there are yet more compounds that remain to be identified. The present work has identified more chemical compounds from Cola nitida. The presence of a number of FAs revealed in this publication serves as evidence of the potential varied biological applications of the seed. Recent reports on the biotechnological/nanotechnological applications of products of Cola nitida have opened the door to a new dimension of research activities involving the genus, especially with respect to waste management. The kola nut pod, which hitherto was considered a waste product, is being converted to useful products - turning waste into wealth. With the aid of well-planned quantitative HPLC analysis of the methanol extract of Cola nitida, some of the unknown compounds can be isolated and structural elucidation carried out. The chemicals identified in the kola nut can be derivatised by functional group inter-conversion to more potent and less harmful compounds for both industrial and medicinal applications.

\section{Conclusions}

Previous research on Cola nitida have established the presence of<smiles>Cn1c(=O)c2c(ncn2C)n(C)c1=O</smiles>

Compound 1. 1,3,7-trimethyl-1 $H$-purine-2,6(3H,7H)-dione (Caffeine). xanthine alkaloids, catechins, epicatechins, anthocyanidins and its oligomers (proanthocyanidins). However, from the ESI-MS experiments, we discovered there are more compounds yet to be identified and structurally elucidated. In this report, the FAs and sugars present in Cola nitida have been identified using the GCMS (FAME and TMS derivatives of the extracts). With analytical Py-GC-MS experiment, the constituents of thermal decomposition of Cola nitida were also identified and compared with those of extracted biomass. In the antimicrobial assay, $\mathrm{CH}_{3} \mathrm{OH}$ extract and solvent fractions showed no activity against Shigella Spp. but were effective against most of the tested microbes. The N-hexane fraction was ineffective in both antimicrobial and antioxidant assays. Caffeine was ineffective in antioxidant assay, but exhibited appreciable activity against Bacillus cereus, Escherichia coli and Aspergillus niger. The butanol fraction displayed higher antioxidant activity than the $\mathrm{CH}_{3} \mathrm{OH}$ extract, which might be due to the higher concentration of phenolic compounds in the butanol fraction.

\section{Acknowledgments}

The corresponding author wishes to acknowledge the Tertiary Education Trust Fund (TETFund) Conference grant from Obafemi Awolowo University to present part of this report at the $4^{\text {th }}$ International Pharma \& Clinical Pharmacy Congress, November 07-09, 2016, Las Vegas, Nevada, USA.<smiles>CCCCCCCCCCCCCCCC(=O)O</smiles>

Compound 2. n-Hexadecanoic acid. 


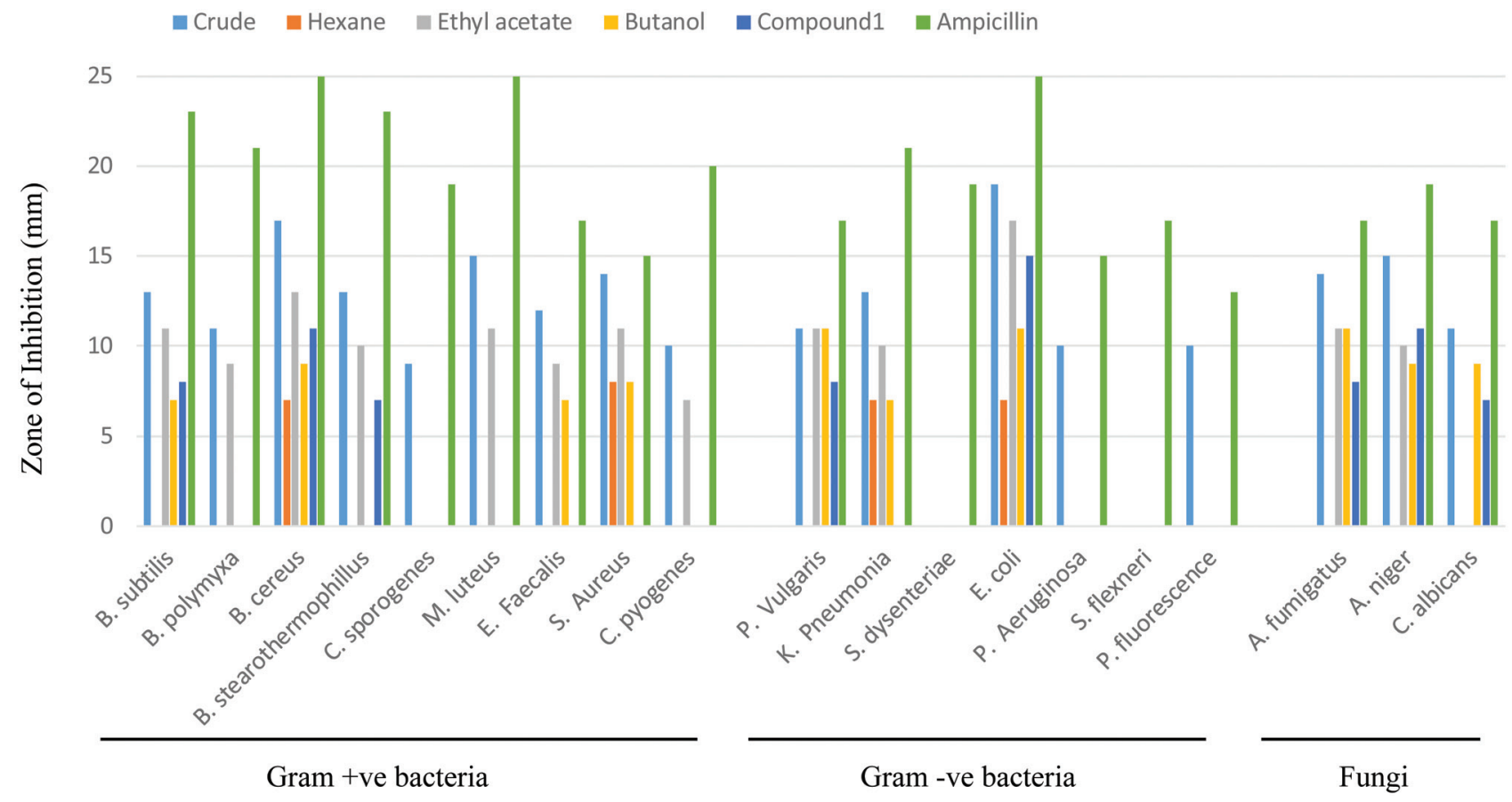

Fig. 4. Antimicrobial experiment against selected fungi, Gram-positive and Gram-negative bacteria.

\section{Conflict of interest}

The authors have no conflict of interests related to this publication.

\section{Author contributions}

Originator of the research idea and supervising the work (JKA), involving in isolation and antimicrobial experiments (SBO), assisting in the antimicrobial study (DAA), involving in the chemical/instrumental analyses (AGM).

\section{Supporting Information}

Supplementary material for this article is available at https://doi. org/10.14218/JERP.2017.00015.

Table S1. In vitro antimicrobial activity of the extracts and compound 1 (caffeine) against selected microbes.

\section{References}

[1] Keay RWJ, Onochie CFA, Stanfield DP. Nigeria trees FRIN Ibadan Vol II. 1964.

[2] Olorunnisola OS, Adetutu A, Afolayan AJ. An inventory of plants commonly used in the treatment of some diseases conditions in Ogbomoso. J Ethnopharmacol 2015;161:60-68. doi:10.1016/j. jep.2014.10.001.

[3] Asogwa EU, Anikwe JC, Mokwunye FC. Kola production and utilization for economic development. African Scientist 2006;7(4):217-222.

[4] Food and Agriculture Organization. Fruit-bearing forest trees. Rome: 1982.

[5] Ogutuga DBA. Chemical composition and potential commercial uses of kolanuts Cola nitida (vent) Schott and Endlicher. Ghana Journal Agricultural Science 1975;8:121-125.

[6] Niemenak N, Onomo PE, Fotso Lieberei R, Ndoumou DO. Purine alkaloids and Phenolic compounds in three Cola species and Garcinia cola grown in Cameroon. S Afr J Bot 2008;74(4):629-638. doi:10.1016/j. sajb.2008.03.003.

[7] Atawodi SE, Pfundstein B, Haubner R, Spiegelhalder B, Bartsch H, Owen RW. Content of Polyphenolic Compounds in the Nigerian Stimulants Cola nitida ssp. alba, Cola nitida ssp. rubra A. Chev, and Cola acuminata (Schott \& Endl) and Their Antioxidant Capacity. J Agric Food Chem 2007;55(24):9824-9828. doi:10.1021/jf0721038.

[8] Kubata BK, Nagamune K, Murakami N, Merkel P, Kabututu Z, Martin SK, et al. Kola acuminata proanthocyanidins: a class of anti-trypanosomal compounds effective against Trypanosomal brucei. Int J Parasitol 2005;35(1):91-103. doi:10.1016/j.ijpara.2004.10.019.

[9] Atawodi SE, Mende P, Pfundstein B, Preussmann R, Spiegelhalder $B$. Nitrosatable amines and nitrosamide formation in natural stimulant: C. acuminata, C. nitida and Garcinia cola. Food Chem Toxicol 1995;33(8):625-630. doi:10.1016/0278-6915(95)00035-Z.

[10] Odebode AC. Phenolic compounds in Kolanut (C. nitida and C. acuminata) (Sterculiaceaea). Revista de Biolologia Tropical 1996;44(2):513515.

[11] Lowe H, Watson C, Badal S, Peart P, Toyang N, Bryant J. Promising efficacy of the Cola acuminata plant: a mini review. Adv Biol Chem 2014;4(4):240-245. doi:10.4236/abc.2014.44029.

[12] Williamson EM, Driver S, Baxter K. Stockley's Herbal Medicines Interactions, 2nd Edition. London: Pharmaceutical Press. 2013.

[13] Mitani H, Ryu A, Suzuki T, Yamashita M, Arakane K, Koide C. Tropical application of plant extracts containing xanthine derivatives to prevent UV induced wrinkle formation in hairless mice. Photodermatol Photoimmunol Photomed 2007;23(2-3):86-94. doi:10.1111/j.16000781.2007.00283.x.

[14] Lateef A, Oloke JK, Gueguim-Kana EB, Raimi OR. Production of fructosyltransferase by a local isolate of Aspergillus niger in both submerged and solid substrate media. Acta Alimentaria 2012;41(1):100117. doi:10.1556/AAlim.41.2012.1.12.

[15] Lateef A, Azeez MA, Asafa TB, Yekeen TA, Akinboro A, Oladipo IC et al. Cola nitida-mediated biogenic synthesis of silver nanoparticles using seed and seed shell extracts and evaluation of antibacterial 
activities. BioNanoSci 2015;5(4):196-205. doi:10.1007/s12668-0150181-x.

[16] Lateef A, Azeez MA, Asafa TB, Yekeen TA, Akinboro A, Oladipo IC, Azeez, et al. Biogenic synthesis of silver nanoparticles using a pod extract of Cola nitida: Antibacterial, antioxidant activities and application as a paint additive. Journal of Taibah University for Science 2016;10(4):551-562. doi:10.1016/j.jtusci.2015.10.010.

[17] Olajire AA, Abidemi JJ, Lateef A, Benson NU. Adsorptive desulphurization of model oil by Ag nanoparticles-modified activated carbon prepared from brewer's spent grains. J Environ Chem Eng 2017;5(1):147-159. doi:10.1016/j.jece.2016.11.033.

[18] Lateef A, Ojo SA, Elegbede JA, Azeez MA, Yekeen TA, Akinboro A. Evaluation of some biosynthesized silver nanoparticles for biomedical applications: hydrogen peroxide scavenging, anticoagulant and thrombolytic activities. Journal of Cluster Science 2017;28(3):13791392. doi:10.1007/s10876-016-1146-0.

[19] Azeez L, Lateef A, Adebisi SA. Silver nanoparticles (AgNPs) biosynthesized using pod extract of Cola nitida enhances antioxidant activity and phytochemical composition of Amaranthuscaudatus Linn. Applied Nanoscience 2017;7(1-2):59-66. doi:10.1007/s13204-0170546-2.

[20] Lateef A, Ojo SA, Folarin BI, Gueguim-Kana EB, Beukes LS. Kolanut (Cola nitida) mediated synthesis of silver-gold alloy nanoparticles: antifungal, catalytic, larvicidal and thrombolytic applications. Journal of Cluster Science 2016;27(5):1561-1577. doi:10.1007/s10876-0161019-6.

[21] Jaksa S, Endrini S, Umeda M, Izzah WN, Zen WM, Othman F, et al. Effects of Cola nitida on tumour marker enzymes in rat liver during hepatocarcinogenesis. J Med Plant Res 2013;7(18):1222-1226. doi:10.5897/JMPR11.260.

[22] Buraimoh AA, Sumanu A, Ojo SA. Histological observations of the cerebellum of wistar rat following the administration of ethanolic extract of Cola nitida. Annals of experimental Biology 2014;2(1):58-62.

[23] Adebayo SA, Oladele OJ. Medicinal values of kolanut in Nigeria: an implication for extension services delivery. Life Sciences Journal 2012;9(2):887-891.

[24] Wei L, Liang S, McDonald AG. Thermophysical properties and biodegradation behavior of green composites made from polyhydroxybutyrate and potato peel waste fermentation residue. Ind Crops Prod 2015;69:91-103. doi:10.1016/j.indcrop.2015.02.011.

[25] Wei L, McDonald AG, Freitag C, Morrell JJ. Effects of wood fiber esterification on properties, weather ability and biodurability of wood plastic composites. Polym Degrad Stab 2013;98(7):1348-1361. doi:10.1016/j.polymdegradstab.2013.03.027.

[26] Irobi ON, Moo-Young M, Anderson WA, Daramola SO. Antimicrobial activity of Bark extract of Bridelia ferruginea (Euphorbiaceae). J Ethnopharmacol 1994;43(3):185-190. doi:10.1016/03788741(94)90041-8.

[27] Russell $A D$, Furr JR. The Antibacterial activity of a new chloroxylenol preparation containing ethylenediamine tetraacetic acid. J Appl Bacteriol 1977;43(2):253-260. doi:10.1111/j.1365-2672.1977. tb00749.x

[28] Brand-Williams W, Bondet V, Berset C. Kinetics and mechanisms of antioxidant activity using the DPPH Free Radical method. Lebensmit-
tel-Wissenschaft und-Technology 1997;30(6):609-615. doi:10.1006/ fstl.1997.0240.

[29] Mailard MR, Hostettmann KJ. Determination of saponins in crude plant extracts by liquid chromatography-thermospray mass spectrometry. J Chromatogr A 1993;647(1):137-146. doi:10.1016/00219673(93)83333-N.

[30] Price KR, Eagles J, Fenwick GR. Saponin composition of 13 varieties of legume seed using fast atom bombardment mass-spectrometry. J Sci Food Agric 1988;42:183-193. doi:10.1002/jsfa.2740420211.

[31] Mauri P, Pietta P. Electrospray characterization of selected medicinal plant extracts. J Pharm Biomed Anal 2000;23(1):61-68. doi:10.1016/ S0731-7085(00)00264-8.

[32] Mauri PL, lemoli L, Gardana C, Riso P, Simonetti P, Porrini M, et al. Liquid chromatography/electrospray ionization mass spectrometric characterization of flavonols glycosides in tomato extract and human plasma. Rapid Commun Mass Spectrom 1999;13(10):924-931. doi:10.1002/ (SICI)1097-0231(19990530)13:10<924::AID-RCM588>3.0.CO;2-G.

[33] Cui M, Song F, Zhou Y, Liu Z, Liu S. Rapid identification of saponins in plant extracts by electrospray ionization multi-stage tandem mass spectrometry and liquid chromatography/tandem mass spectrometry. Rapid Commun MassSpectrom 2000;14(14):1280-1286. doi:10.1002/ 1097-0231(20000730)14:14<1280::AID-RCM26>3.0.CO;2-C.

[34] Schöpke T, Hiller K, Wray V, Nimtz M. Application of MS-MS for the Rapid, Comparative Analysis of Saponin Mixtures as Exemplified by the Deacylated and Partially Deacylated Triterpenoid Saponins of Bellis annua. Planta Med 1996;62(4):336-340. doi:10.1055 /s-2006-957897.

[35] Connor WE. Importance of n-3 fatty acids in health and disease. Am J Clin Nutr 2000;71(1 Suppl):171S-175S.

[36] Simpoulos AP. The importance of the ratio of omega-6/omega-3 essential fatty acids. Biomed Pharmacother 2002;56(8):365-379. doi:10.1016/S0753-3322(02)00253-6.

[37] Cakir A. Essential oil and fatty acid composition of the fruits of Hippophaerhamnoides L. (Sea Buckthorn) and Myrtus communis L. from Turkey. Biochem Syst Ecol 2004;32(9):809-816. doi:10.1016/j. bse.2003.11.010.

[38] Nassar-Abbas SM, Halkman AK. Antimicrobial effect of water extract of Rhus coriaria L. on the growth of some food-borne bacteria including pathogens. Int J Food Microbiol 2004;97(1):63-69. doi:10.1016/j. ijfoodmicro.2004.04.009.

[39] Mori A, Nishino C, Enoki N, Tawata S. Antibacterial activity and mode of action of plant flavonoids against Proteus vulgaris and Staphylococcus aureus. Phytochemistry 1987;26(8):2231-2234. doi:10.1016/ S0031-9422(00)84689-0.

[40] Zheng WF, Tan RX, Yang L, Liu ZL. Two flavones from Artemisia giraldii and their antimicrobial activity. Planta Med 1996;62(2):160-162. do :10.1055/s-2006-957841.

[41] Eloff JN. Which extracts should be used for the screening and isolation of antimicrobial components from plants. J Ethnopharmacol 1998;60(1):1-8. doi:10.1016/S0378-8741(97)00123-2.

[42] Lin J, Opoku AR, Geheeb-Keller M, Hutchings AD, Terblanche SE, Jäger AK, et al. Preliminary screening of some traditional zulu medicinal plants for anti-inflamatory and antimicrobial activities. J Ethnopharmacol 1999;68(1-3):267-274. doi:10.1016/S0378-8741(99)00130-0. 